\title{
角端型流入口を有する急勾配管路における \\ 管・開水路遷移と履歴特性

\author{
HYSTERESES AND TRANSIENT PHENOMENA IN A STEEP \\ CIRCULAR CONDUIT WITH A SHARP EDGED INLET
}

\author{
宇井正和 \\ Masakazu UI \\ 正会員 工博 東京都立大学助手 工学部土木工学科 ( $\overline{\mathrm{T}}$ 192-03 八王子市南大沢 1-1)
}

\begin{abstract}
Construction of underground big rivers for peak cut of runoff forces researchers to investigate the problems of unsteady flow in a conduit at a heavy rain storm and improve the analytical methods for the flow. The important problem in this flow lies in transient phenomena between part-full and full flow, which have been reported by author to be strongly related with the shape of pipe inlet. But the effects and the transient properties are not incorporated sufficiently in the analytical methods. In this paper, the transient properties are investigated according to the hysteresis of the relation between head water level and discharge, and a hydraulic model is proposed to simulate the transient flow in the conduit.
\end{abstract}

Key Words : transient flow, pipe flow, inlet flow, air pocket

\section{1. 緒論}

豪雨時における都市河川のピークカットを目的とし た大型地下河川が多くの大都市で構築されている。こ れらの管渠では流れが常に満管あるいは満管近くの水 深で流れることが想定されるため，常に管・開水路相 互の遷移現象や，内部に閉じこめられるエアーポケッ トの挙動がその管路の疎通に影響を及ほすす。 しかし， 管・開水路遷移に関して，それが何時，何処でどのよ うに発生するのかの水理学的説明はなされていない.

下水管渠を対象とした管路内流れの解析法は幾つか 提案されているが 1),2)，その遷移特性を考慮した方法 は殆ど見あたらない. そして，これらの遷移やエアーポ ケットの処理の複雑さを回避するために, Preissmann らの提案するスロットモデル 3)を利用することが多い. しかしこのスロットモデルは，管頂に幅の狭い水路を 仮定し管路内被圧をその水路内での水位として扱うた め，管路流れの特徵であるエアーポケットや負圧の発 生を十分に説明できない欠点を有するものである.

筆者は急勾配円形管路での管・開水路遷移が管口形状 と密接に関係していることを多くの実験を通して確認 し，報告してきた ${ }^{4), 5)}$.

管口形状の管内流への影響に関する研究としては 1950 年代の米国におけるカルバート内の流況問題が上げら
れる。これらはフリーウェイの建設に際し多くのカル バートが必要になったが，管口形状の影響のため流入 水位を上げても管内を満管流にすることが出来ず，明 確な設計水路断面が得られなかったことによる．解決 案として管口断面を斜めにした”hood-inlet”6) が考案 されたが，管口形状と遷移現象については未解決のま ま残された，近年諸外国でも都市化の拡大に伴い雨水 排水の問題が生じ, 下水管渠内の流れの研究が進めら れているものの，管・開水路遷移に関しては十分な検 討が為されているとはいえない.

ここでは，実際によく見られる角端型流入口の付い た急勾配管路を用い，流入水位が上昇あるいは下降す るにつれて管路内が満管や開水路流れへと遷移する現 象を実験を通して体系的に整理すると共に，その解析 上での水理モデルを提案するものである.

筆者は既往の論文 ${ }^{4), 5)} に$ に扔いて, 角端型流入口を有 する急勾配管路における流入水位と管内流量との関係 が図-1(1/50 管路勾配) のような履歴特性を有すること を報告してきた。ここで流入水位とは管路上流側の整 流水槽水位 $(\mathrm{E})$ であり，管内流量 $(\mathrm{Q})$ はその水位によっ て管路の中へ供給される流量である. 図中の $\mathrm{A}, \mathrm{B}, \mathrm{C}, \sim$ $\mathrm{F}$ は履歴特性の中で流況が変化する点を示している.

図-1の履歴特性によって管内流況を考察する，流入 
水位が低いときは管口部は開水路状態で流入し，管口 が閉塞されるのは B 点に達した時である。しかし，流 入水位が管径の数倍の高さでも管路内は開水路状態で 流れ， $\mathrm{C}$ 点に至って初めて全管が満管流になるが, 同 時に流入水位は D 点まで下がる，満管になった後は水 位が $\mathrm{E}$ 点に至るまで満管流れの状態を維持し， $\mathrm{E}$ 点で 漸く管口からエアーの連行が始まる．E点での水位は 極めて低く, $\mathrm{E} / \mathrm{d}$ は 1.2 1.3 程度である. $\mathrm{E}$ 点から $\mathrm{F}$ 点までは管路の中にエアーポケットが成長し，管路は 開水路流れと見なしうる程になるが，管路全体が完全 に開水路流れ $(\mathrm{F})$ になると, 流入水位が急に $\mathrm{E} / \mathrm{d}=0.3$ $\sim 0.4$ も上昇して再び $\mathrm{AC}$ 曲線上 $(\mathrm{G})$ に移り, エアーポ ケットの存在効果の大きいことが示される.

これらの履歴特性の中で, 区間 $\mathrm{AB}$ は管口部で限界 水樑をとるものと考えられるので，その条件式から流 入水位と管内流量との関係が導かれ，また管内流況も S2 で変化することが分かる. 区間 DE は管路系全体が 満管状態で流れているため, 動水勾配や管路の摩擦損 失係数を与えることによって流入水位と管内流量との 関係は容易に導くことが出来る。しかし，区間 $\mathrm{BC}$ は 開水路流れから管路流れへ，また区間 $\mathrm{EF}$ はその逆の 遷移の生ずる区間であり，流れに対する管路としての 特性が明確に顕れる領域である。

ここでは急勾配管路における管・開水路遷移が流入 水位と管内流量との履歴特性をもたらすものと認識し, その過程に扔ける管路への流入状況が管口近傍で最小 水位を取るという水理モデルを想定し，そこから導か れる結果と実験結果とを比較し，モデルの有効性を検 討するものである。

\section{2. 管・開水路遷移過程についての実験的説明}

角端型流入口をもつ急勾配管路では等流状態を維持 しながら全体的に満管流になるのでもなく又開水路流

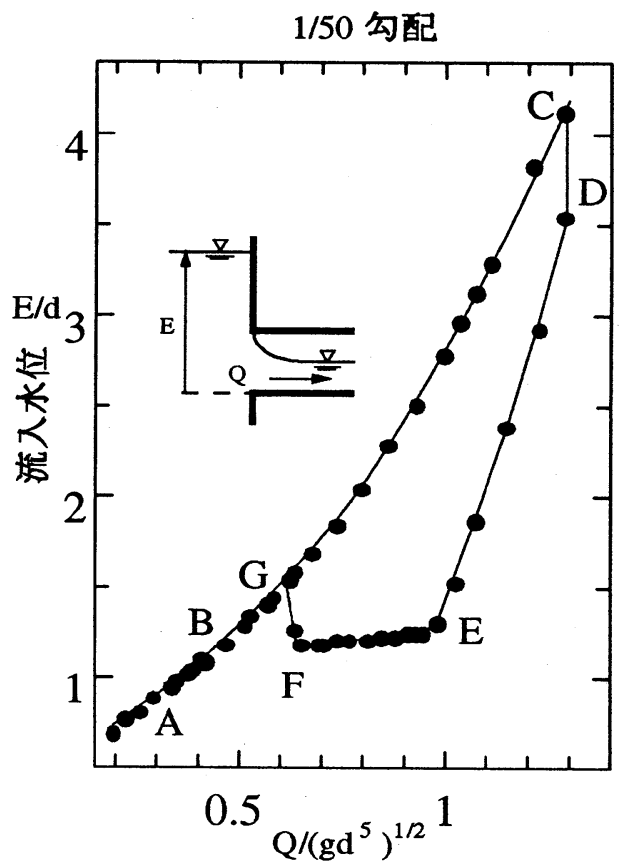

図-1：履歴特性

れになるのでもない.これは $\left.\mathrm{Li}^{7}\right)$ らが実験的に示した “水面の不安定性”に従って満管になるものと考えてい る. Li らの論文にもその水面形が図示されているが, 筆 者の観察した遷移の過程を図-2,3に示す.これらの遷移 現象は内径 $10 \mathrm{~cm}$, 長さ $14 \mathrm{~m}$ のアクリル製管路に, 三 角堰からの既知流量を整流水槽を通して定常的に変化 させながら計測したものである。

\section{1 管路勾配 $1 / 90$ での遷移状況}

図-2,3 は管路勾配 $1 / 90$ と殆ど緩勾配と言える $1 / 200$ に打ける，管・開水路遷移状況である，管口部は左端で あり，空気の部分をハッチし水流と区別している．水面 形についている数字は流量を変化させた回数であり, 回 数を追うことによって，水面形の变化を表した，図-2(a) での水面は既に 11 12 ステップ後の流量に対応したも のであり, 等流水深は $\mathrm{h} / \mathrm{d}=0.7 \sim 0.8$ 程度であるものの, 流入水位は管径の倍以上の高さである。この段階では

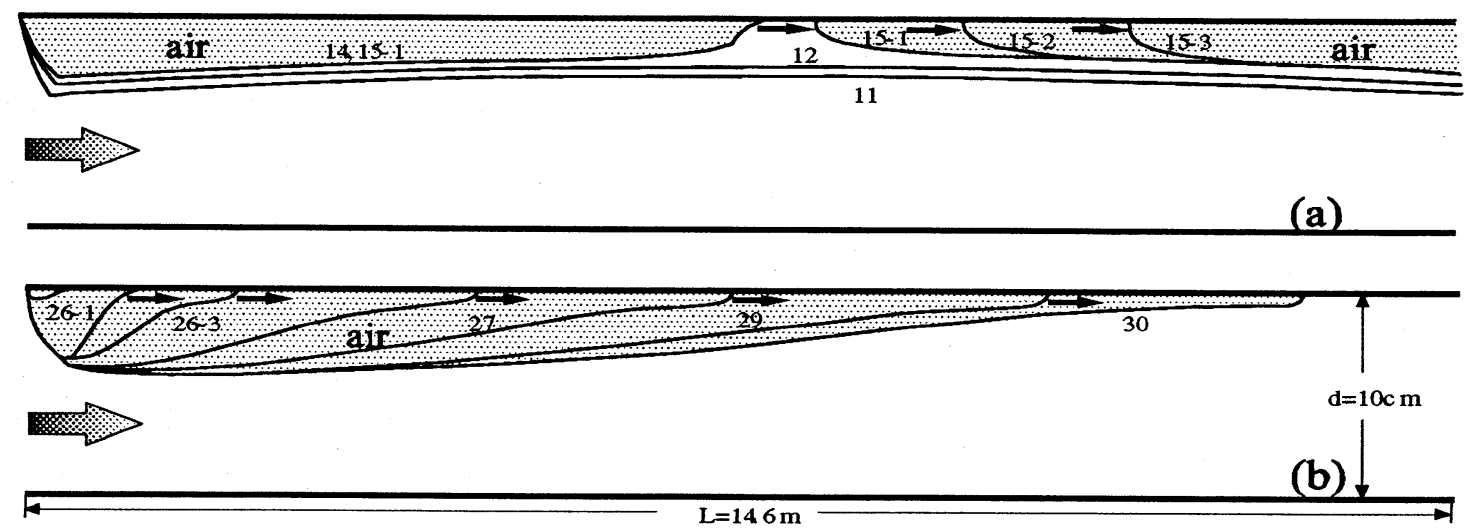

図-2：遷移過程 1/90（a) 管路流れへ，(b) 開水路流れへ 


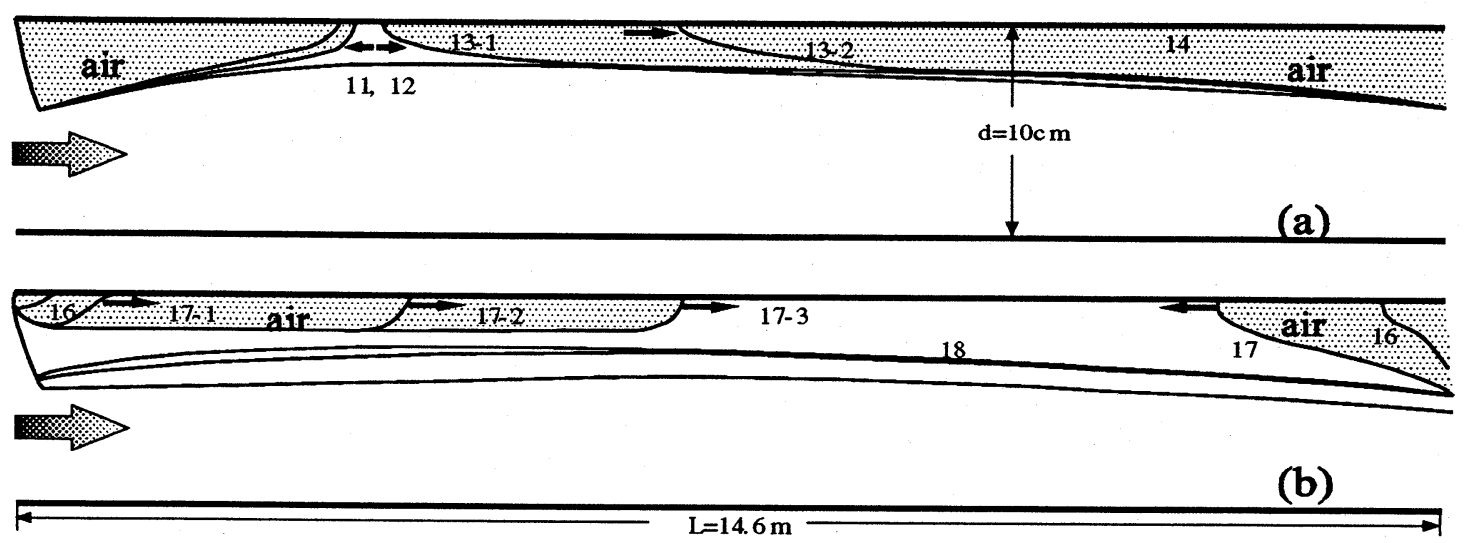

図-3：遷移過程 1/200（a) 管路流れへ, (b) 開水路流れへ

管口部で生ずる最小水位に僅かの変化が見える。しか し, 14 番の水面から管路中央辺りの水面に不安定が生 じ，管頂に接触するようになる．するとそこに生じた 満管流の部分は下流側へと伸びていき，流量の増加を 待たずに管路下流端まで満管状態にする，上流側に閉 じこめられたエアーとの管・開水路境界面は明確な跳 水状態と見なすことが出来る，そのエアーは管口から は抜け出すことができず，跳水に巻き込まれながら管 頂に沿って泡状で排出されていく．このエアーを排出 して全管を満管状態にするには更なる流量の増加が必 要である. 完了したのは 19 ステップ後であった。

図-2(b) は流入水位が降下して管口からエアーが連行 され，管内にエアーポケットを発達させながら全管が 開水路状態になるまでを示す，管口からエアーが入り 始めたのはステップ 26 の時で, 管口近傍の水槽水面は 引き込まれるように低下し，管口部直下には小さな工 アーポケットが発生する。これは供給水量の僅かな減少 に対しても大きく伸長する．図においても2 3 ステッ プ後には管口から $7 \mathrm{~m} \sim 10 \mathrm{~m}$ までがほとんど開水路状態 となり，30 ステップにおいては完全に開水路流れに移 行する.この遷移過程では管口部での最小水位がほと んど同じ值 $(\mathrm{h} / \mathrm{d} \sim 0.6)$ を維持していることが特徽であ る. それより下流側の水位は S3 の水面形にそって増す ものと予想され, ステップ 31 における下流端水位は管 頂より僅かに低いだけである。

\section{2 管路勾配 $1 / 200$ での遷移状況}

図-3 (a),(b) に緩勾配に極めて近い管路での遷移状況 を示す. 1/90勾配と異なるのは水面の不安定の生ずる 位置が管口から約 $3 \mathrm{~m}$ であり, かなり上流側で発生して いることである，水面が管頂に接触すると満管状態は わずかな供給流量の増加で下流へと進んでいく．ここ での最小水位は流量変化に対し一定値を保つようにも 見える。供給流量が減少し管口からエアーが連行され るのは流入水位が $1.2 d$ 辺りであり, それに伴うエアー ポケットの大きさは管路中央辺りまで伸長するが, 同
時に管路下流側からもキャビティが進入する ((b) 図参 照). 緩勾配管路の場合には管口からのエアーの連行以 前に下流端からキャビティの溯上が始まるが, 満管流 で流しうる動水勾配との関保が要因と考えている。

\section{3. 遷移領域における水理モデル}

\section{1 区間 BC への水理モデルの適用}

以上のような流況観察に基づき，区間 $\mathrm{BC}$ および $\mathrm{EF}$, 即ち管・開水路遷移過程では最小水位の仮定が想定され た. 整流水槽からの流れは管口近傍で最小水位をとる ものとし，そこでは管口から流入してきた流れが一様 となり, 水面が管路と平行な最小流水断面をとる. した がってそれより下流側では，その最小水位を初期水位 とした $\mathrm{S} 3$ 型の不等流水面形が構成される (図-4 参照).

まず整流水槽から管路への流入はスルースゲートか らの噴流の形を取る. 最小水位の位置は管口の近傍で あり，水流の運動に対して管路勾配や管路壁面からの 摩擦抵抗は小さく無視できるものと考える。したがっ て, 整流水槽水面と最小水位水面との間にベルヌイの 式が適用できる。

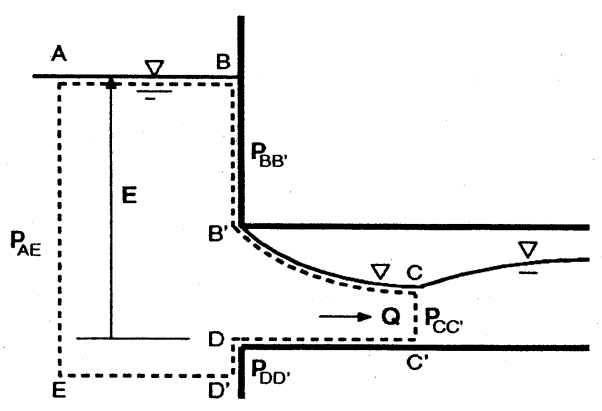

図-4：管口での流況と検查面

$E=\left(\alpha+f_{e}\right) \frac{v_{c}^{2}}{2 g}+\eta_{c}+\frac{p_{a}}{\rho g}=\left(\alpha+f_{e}\right) \frac{Q^{2}}{2 g A_{c}^{2}}+\eta_{c}+\frac{p_{a}}{\rho g}$ (1)

ここでは整流水槽水位を管口底部からの水位として いるため $E$ で表す. $\eta_{c}, v_{c}, A_{c}$ は最小水位断面 Cでの 
水位と平均流速と流水断面積であり, 又 $A$ は管路断面 積である. $p_{a}$ は C 水面上の空気圧である， $\alpha$ はエネル ギー補正係数であるが， $f_{e}$ は管口近傍における流れの 複雑さを単純化したことに対する補正係数であり，実 験との比較によって検討する。

次に，図中の点線で示すような検査面を考えて運動量 の式を適応させる. 断面 $\mathrm{AE}$ での平均流速を $v_{A E}$, そ こに作用する全水圧を $P_{A E}$ と表す. 又断面 $\mathrm{BB}{ }^{\prime}, \mathrm{CC}$ ', DD'に作用する全水圧もそれぞれ $P_{B B^{\prime}}, P_{D D^{\prime}}, P_{C C^{\prime}}$ と表すと, 運動量の式は以下のようになる。

$$
\rho Q\left(v_{c}-v_{A E}\right)=P_{A E}-P_{B B^{\prime}}-P_{D D^{\prime}}-P_{C C^{\prime}}-p_{a} A
$$

断面 $\mathrm{AE}$ に作用する全水圧は，壁面 $\mathrm{BB}$ ' および $\mathrm{DD}$ 'へ も静水圧分布が作用しているものと仮定すると，ちょ うど管路断面 B'D に作用する圧力のみが残る．即ち，

$$
P_{A E}-P_{B B^{\prime}}-P_{D D^{\prime}}=\rho g A(E-d / 2)
$$

$v_{A E} \approx 0$ とみなせるから

$$
\rho Q v_{c}=\rho g A\left(E-d / 2-\frac{p_{a}}{\rho g}\right)-P_{C C^{\prime}}
$$

式 (1) および式 (3) は管口が閉塞された時の管内流量 と流入水深を結ぶ方程式であり，その特徴を検討する. 両式から $\mathrm{E}$ を消去し， $P_{c c^{\prime}}$ を $P_{c}$ と書き直すと,

$$
\rho \frac{Q^{2}}{A_{c}^{2}}=\rho g A\left(\eta_{c}-\frac{d}{2}+\left(\alpha+f_{e}\right) \frac{Q^{2}}{2 g A_{c}^{2}}\right)-P_{c}
$$

両辺を $\rho g A$ で割ると, 次式のように整理できる.

$$
\eta_{c}+\frac{\alpha Q^{2}}{2 g A_{c}^{2}}-\frac{Q^{2}}{g A A_{c}}-\frac{P_{c}}{\rho g A}=\frac{d}{2}
$$

式 (4)において, $A_{c}$ および $P_{c}$ は水涾 $\eta_{c}$ の関数であ るから， $Q$ を与えることによって上式を満たす最小水 位 $\eta_{c}$ を求めることができる.

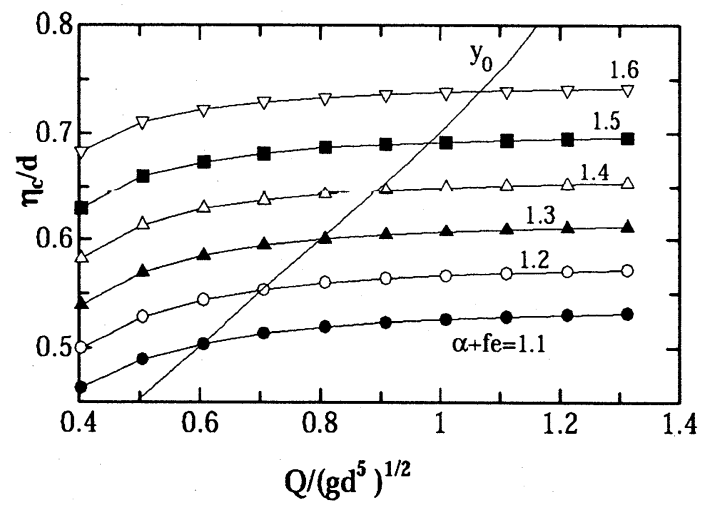

図-5: 最小水位と流量

図-5 は係数 $\alpha+f_{e}$ の值を種々変化させたときの流量 と最小水位との関係である. 四から, 流量の変化に対 して最小水位の変化は単調であり又微少と言える。し
かし係数 $\alpha+f_{e}$ による効果は大きく，それが $1.1 \sim 1.6$ へ変化するときに, $\eta_{c} / d$ は 0.2 以上もの差が生じてい る. 図中の斜めの実線は $1 / 50$ 管路勾配での等流水深を 表している，管路において最小水位より下流側の水面 が等流水深へ漸近するならば，最小水位は対応する等 流水深より小さくなければならず, 有効流量範囲を決 めるための条件となる， $\eta_{c}$ を(1) 式へ代入すると，流 量 $Q$ と水槽水位 $E$ との関係が得られる.この時管内圧 $p_{a}$ に関しては，区間 $\mathrm{BC}$ が $\mathrm{C}$ 点近傍を除いてほとんど 開水路的に流れているため, $p_{a} \sim 0$ と見なした.

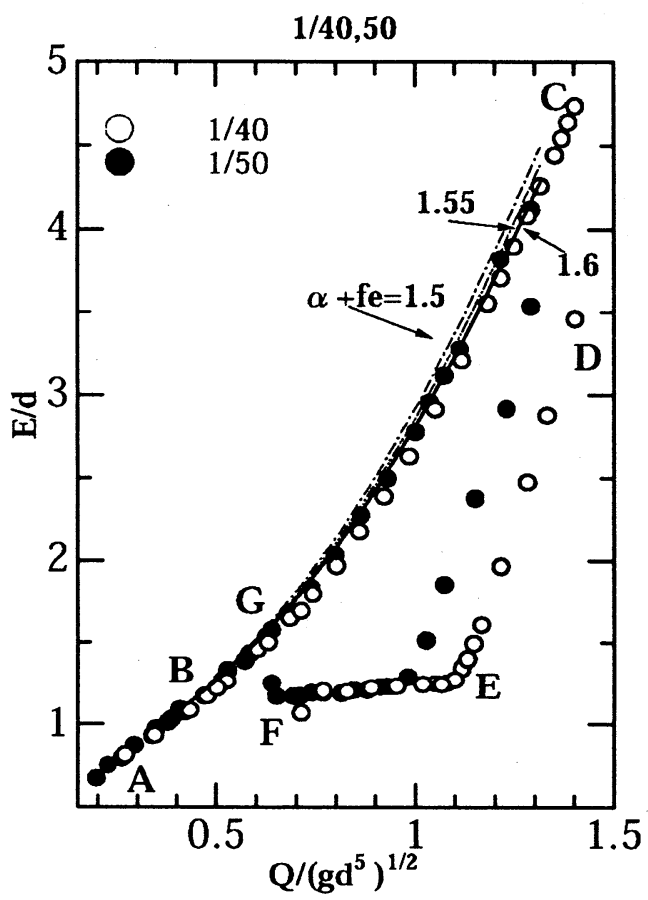

図-6：区間 BCにおける $\mathrm{E}-\mathrm{Q}$ 曲線

図-6 は $E-Q$ 関係を勾配 $1 / 40$ と $1 / 50$ の実測值と共に 図示したものである. $E-Q$ 曲線は $\alpha+f_{e}$ が増すと共 に右側に傾き， $\alpha+f_{e}=1.6$ の場合に最も実験結果と 合致する. 図中 C 点の近傍は管路端から満管流れが上 流に向かって遡上している領域であるが, この近くで も実測值との良好な一致が得られるのは式 (1) および 式 (3) が被圧状態でも有効であることを証明している.

\section{2 区間 $\mathrm{EF}$ への水理モデルの適用}

区間 $\mathrm{EF}$ は連行されたエアーポケットと満管流の共存 する領域である。この区間での管口部への流入は図-7 の管口部近傍の流況のように, BC 区間とは異なり水槽 水面が管口へ吸い込まれるように低下し，限界水深を 経て流入するように見える。しかし，ここでも水面は $\mathrm{BC}$ 区間と同様に最小水位をとり，その後 $\mathrm{S} 3$ の不等流 水面形にそって変化するものと考える．下流側の満管 流れへは, S3 で変化している水面が途中で跳水して出 来るものとした. 水槽上の水面 $\mathrm{A}$ 点と最小水位との間 
にベルヌイの式を適用すると，

$$
E+\frac{v_{A}^{2}}{2 g}=\eta_{c}+\left(\alpha+f_{e}\right) \frac{v_{c}^{2}}{2 g}+\frac{p_{a}}{\rho g}
$$

また，図-4の点線で囲まれた区間と同様に運動量の式 を適用すると, 次式が得られる。

$$
\rho Q\left(v_{c}-v_{A}\right)=P_{A}-P_{c}-\frac{p_{a}}{\rho g} A
$$

ここで, $P_{A}=\rho g A(E-d / 2)$ とし, 水槽水面上の $\mathrm{A}$ 点 での流水断面積 $A_{A}$ は C 点での断面積 $A_{c}$ より十分大 きいと仮定すると， $v_{A}<v_{c}$ となり $v_{A}$ を省略できる. これらの式は履歴曲線 $\mathrm{BC}$ での方程式と同じであるた め, 最小水位に関する式 (4) と同じ次式が導かれる.

$$
\eta_{c}+\left(\alpha+f_{e}-2 \frac{A_{c}}{A}\right) \frac{Q^{2}}{2 g A_{c}^{2}}-\frac{P_{c}}{\rho g A}=\frac{d}{2} .
$$

この式から得られる最小水位は図-5 と同じであるから $\eta_{c}$ を(5) 式へ代入すれば, 流入水位 $E$ と流量 $Q$ との関 係が得られる。しかし管内压 $p_{a}$ が未定のままである。

次に, この管内圧 $p_{a}$ の算定を行う.

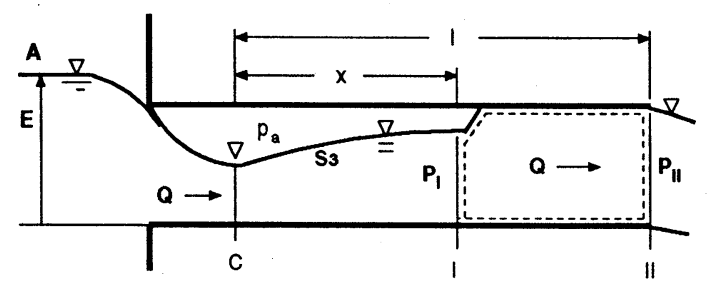

図-7：区間 EF に㧍ける流況と検査面

履歴曲線 (図-1)において, 同じ流量に対する BC 曲線 と $\mathrm{EF}$ 曲線の水頭差に注目する。そして，この差が管内 圧力に上るものと考え，それを流れの運動エネルギーに 対応させて図示したのが図-8 である．図からわかるよ うに,この空気圧 $\left(p_{a} / \rho g d\right)$ と運動エネルギー $\left(v^{2} / 2 g d\right)$ との関倸は，ある点で頭打ちになるまでは直線的に変 化していることが分かる，最小自乗法を用いて管内空 気圧を以下のように表した。

$$
\frac{p_{a}}{\rho g d}=-2.5 \frac{v^{2}}{2 g d}+0.5
$$

この管内圧を式 (5) に代入すると $E$ と $Q$ の関係が得ら れるが, 実験による $\mathrm{EF}$ 曲線と比較してその妥当性を 考察する. 係数 $\alpha+f_{e}$ の值をパラメータとした $E$ と $Q$ の関係は図-9 中に示された細線群である。実測結果と 良く合致するのは係数 $\alpha+f_{e}=1.6$ の場合である事が

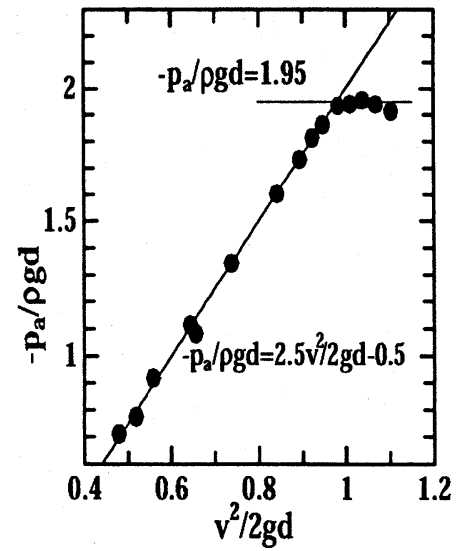

図-8：管内圧力

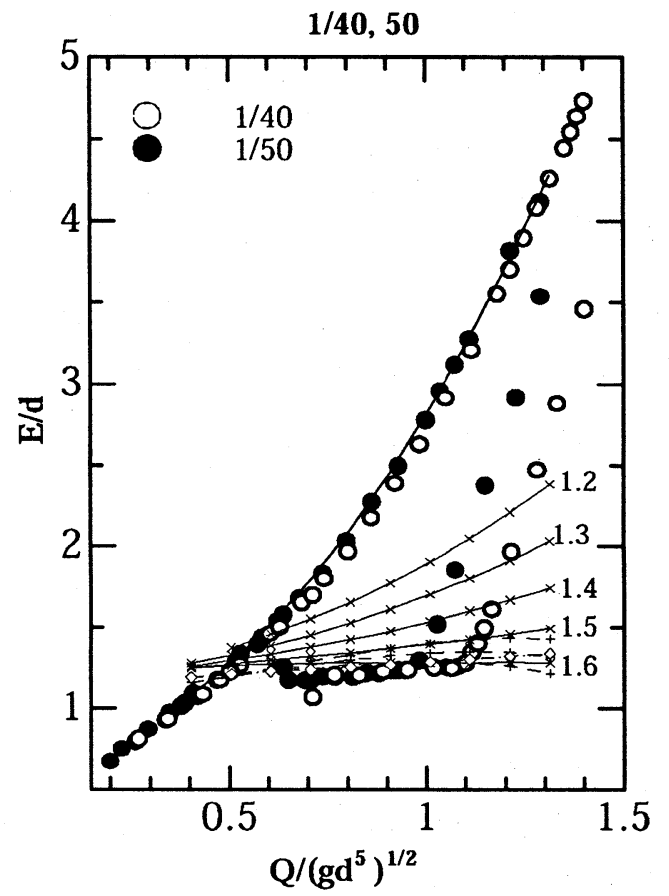

図-9：区間 $\mathrm{EF} に$ におる $\mathrm{E}-\mathrm{Q}$ 曲線

わかる、このモデルによる結果は $\alpha+f_{e}$ が増加するに 従い $E-Q$ 曲線の勾配が緩やかになり, 流量が減少す るに伴いそれらの曲線が一点から発するように収束し， $\mathrm{EF}$ 曲線の特徽と一致することである。

\section{4. 跳水の位置}

流入水位と流量との関係は管口での流況から得られ たが，それらは管路勾配等の管路特性に依存していな い、ここでは，管路の物理的条件に依存するエアーポ ケットの大きさがどのように決まるかを考察する.

最小水位 $\eta_{c}$ から被圧部までの水面は等流水深へ漸近 する不等流水面形の S3 と考えられる。したがって，S3 に沿って変化していく水面形のどこで跳水し, 満管流 の長さがどのように決まるかが問題となる．四-7 のよ うに，跳水直前と管路端を断面 $I$ および $I I$ とした検査 面を考え，そこでの運動量の保存式を適用してみる。断 面 $I$ での水深を $y_{1}$ とし，そこに作用する全水圧を $P_{1}$ 
で表す． $v_{1}, v_{2}$ を各断面での流速とすれば，次式が成 立する。

$\rho Q\left(v_{2}-v_{1}\right)=P_{1}+A_{2} p_{a}-P_{2}+\left(\rho g A_{2} \sin \theta-\pi d \tau_{0}\right)(\ell-\chi)$

ここで $\ell$ は支配断面 C から管路端までの長さであり， $\chi$ は跳水位置までの長さ， $\theta$ は管路勾配， $\tau_{0}$ は壁面摩擦 応力である．断面 $I I$ における全水圧 $P_{2}$ は下流端が放 流状態であるため”0"とした，ここで流れは準定常と考 えているから $A_{1} v_{1}=A_{2} v_{2}=Q$ が成り立つ. 式 (7)に この連続式と, 空気圧の関係式を代入すると次式が導 ける。

$\frac{Q^{2}}{g A_{1} A_{2}}+\frac{P_{1}}{\rho g A_{2}}+(\ell-\chi)\left(S_{0}-S_{f}\right)=\left(1+\frac{5}{4}\right) \frac{Q^{2}}{g A_{2}^{2}}-0.5 d$

ここで $\sin \theta=S_{0}, \frac{\pi d \tau_{0}}{\rho g A_{2}}=S_{f}$ であり, $A_{2}$ は跳水後 の被圧流れであるから管路断面積 $A$ と等しい. 又, $A_{1}$, $P_{1}$ および $S_{f}$ は $y_{1}$ の関数である. 跳水までの水面が $\mathrm{S} 3$ 水面形に沿って変化しているものとすれば, 跳水直前 の水深 $y_{1}$ は断面 $\mathrm{C}$ からの距離 $\chi$ の関数であり, 不等流 水面形の次式から得られる。

$$
\frac{d y}{d \chi}=\frac{S_{0}-S_{f}}{1-\frac{Q^{2} B}{g A^{3}}}
$$

従って，適当な $\chi$ をちて式 (8) と式 (9) が成立するよ うにできれば，その 义は跳水の位置を示すことになる。

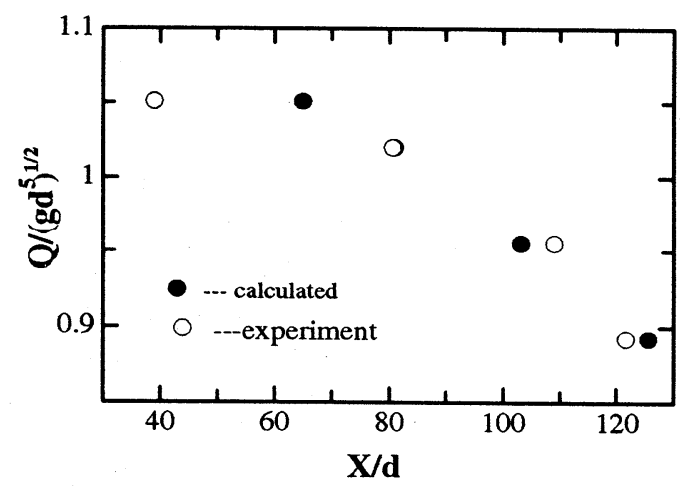

図-10:エアーポケットの長さ

このようにして求めた跳水の位置を図示したものが図10 であり，同じ流量に対する実測值 (。印) と計算值 (・ 印）をプロットしてある. 流量が多い場合, 即ちエアー ポケットの長さが 60 以内では実測値との差が大きいが, それ以上に伸長し満管部分が管路下流側へ押されてく ると両者に良い一致を見ることができる．

5. 結論

角端型流入口を有する急勾配管路に扔ける流入水位 と管内流量の履歴特性を，管内流況が管口近傍で最小
水位を取るという水理モデルを仮定し，その有効性を 検討した.

1) 開水路流れから管路流れへ遷移する (区間 BC) 領域 では管内圧を $p_{a}=0$ とし, ベルヌイの式と運動量の式 から流入水位と管内流量との関保を導びき，それらを 実測結果と比較した. 係数 $\alpha+f_{e}=1.6$ を与えること によって良好な一致を見ることができた， $\alpha=1.1$ とす れば $f_{e}=0.5$ となる.

2) 管水路から開水路流れへの遷移 (区間 $\mathrm{EF}$ ) において は流入水位が極めて低いという特徽があるが，これを $\mathrm{BC}$ 曲線と $\mathrm{EF}$ 曲線の差に相当する管内圧によるものと 考え，区間 BC の場合と同じ計算方法で実験結果との 一致を得ることができた。

3) 運動エネルギー補正係数 $\alpha$ の他に $f_{e}$ という補正係 数を用いたが, 結果的に角端型流入口での損失係数 0.5 と同じ值が得られた. しかし $f_{e}$ の特性に付いてさらに 検討する必要がある。

4) エアーポケットの発達に関しては満足できる結果と はいえない．跳水における共役水深と満管流れでの動 水勾配等の検討が必要と考える。

5）管口近傍で流れが最小水位を取るという水理モデル のみで，傾向が大きく異なる $\mathrm{BC}$ 曲線と $\mathrm{EF}$ 曲線をシ ミュレートできたことはこのモデルが遷移現象におけ る重要な性質を含んでいるものと考えている。

\section{参考文献}

1)Song,C.C.S., Cardle,J.A. and Kim Sau Leung: Transient Mixed-Flow Models for Storm Sewers, ASCE, HY Vol.109, No.11, Nov.1983

2)Capart,H., Sillen, X. and Zech, Y.: Numerical and experimental water transients in sewer pipes, Journal of Hydraulic Research, Vol.35, pp659-716, 1997 No.5 3)Cunge, J.A., Holly, F.M.and Verweg, A.: Practical Aspects of Computational River Hydraulics, Pitman Advanced Publishing Program, 1980

4) 宇井正和, 安川 浩: 流入口形態による管内流況特性, 水理講演会論文集, Vol.37, pp.457-462, 1993

5)M. Ui and H. Yasukawa: Headwater level and discharge in a steep slope pipe, Proceeding of the Third International Conference on Hydrodynamics, pp.511516,1998

6)Blaisdell, F.W.: Hood inlet for closed conduit spillways, ASCE, Vol.86, No.HY5, pp7-31, May, 1960 7)Li,Wen-Hsiung and Patterson,C.C.: Free Outlets and Self-Priming Action of Culverts, ASCE, Vol.82, No.HY3, June, pp1009-1-1009-21,1956

(2001.10.1受付) 